\title{
Physical activity in stroke patients: A scoping review
}

\author{
Ariyati Amin*, Rosyidah Arafat, Rini Rachmawaty \\ Department of Medical Surgical Nursing, Faculty of Nursing, Hasanuddin University, South Sulawesi, Indonesia
}

\section{KEYWORDS}

Aerobic exercise

Exercise

Physical activity

Resistance training

Stroke
SUBMITTED: 25 November 2020

REVISED: 22 January 2021

ACCEPTED: 14 March 2021

ABSTRACT Stroke is the second leading cause of disability and death worldwide with 5.9 million deaths annually. Stroke can be followed by various clinical problems. Impaired motoric function of the extremities is the most severe post stroke disorder experienced and impacts on limitations of daily activities. The main treatment is by doing regular physical activity exercises. This review was conducted to identify physical activities that can be performed by stroke patients. This scoping review was compiled using Arksey and O'Malley's five-stage framework. A total of three databases (i.e., Pubmed, Proquest, and DOAJ) was searched with relevant keyword "physical activity OR exercise AND stroke". The articles selected are published in the last 5 years, in English, and in full text. The literature search retrieved 164 studies to be screened based on the exclusion-inclusion criteria which finally resulted in the 11 studies included in the review. The remaining 11 studies were fully read and data were extracted regarding the type of physical activity, goals, settings and outcomes. Qualitative (i.e., theme analysis) methods have been used to synthesis the data. Based on the results of the review, there are several physical activities that stroke patients can do, such as progressive resistance and balance (PRB) exercises, locomotors exercises: (walking on a treadmill with body weight support and walking on the ground), selective movements of the upper and lower trunk body in the Supine and sit using a stable support / pad or unstable support (Swiss ball), core stability training, aerobic (AT) and resistance training (RT), aerobic training, walking exercises, and task-oriented training. Several physical exercises have been identified where each of these exercises has a purpose and benefit in the recovery of physical functional stroke patients. Physical activity should be done regularly and take into account the duration, intensity, and frequency of the exercise based on patient's ability and stamina.

(c) The Journal 2021. This article is distributed under a Creative Commons Attribution-ShareAlike 4.0 International license.

\section{Introduction}

Stroke is the second leading cause of disability and death worldwide with 5.9 million deaths annually ${ }^{1,2}$. Stroke can be followed by various clinical problems. However, impaired motor function of the extremities is a major problem that is often found among sufferers. As much as $50 \%$ of stroke survivors experience hemiplegic and hemi paresis, fatigue, and instability of posture and balance that cause difficulty in walking and carrying out daily activities ${ }^{3,4}$. Six months after stroke, the problems can persist and result in long-term disability ${ }^{4,5}$.

The main handling of motor function disorders of the extremities can be through routine physical activity, both light to moderate physical activity.

\footnotetext{
*Correspondence: arie.ns.08@gmail.com

Department of Medical Surgical Nursing, Faculty of Nursing, Hasanuddin University, South Sulawesi, Indonesia. Jl. Perintis Kemerdekaan Kampus Tamalanrea, KM.10 Makassar, 90245.
}

Physical activity exercise increases muscle strength, functional capacity, ability to perform daily activities, gait, balance, improved cardiorespiratory measures and quality of life, and prevents cerebrovascularrelated risks ${ }^{6-11}$. Accordingly, post stroke patients are required to perform routine physical activity exercises in the rehabilitation phase so that the decrease in motor function of the extremities does not lead to long-term disability.

Stroke sufferers with low physical activity (less than four hours per week) have a 91\% chance of experiencing secondary complications such as disability, pressure ulcer, pneumonia, and heart problems ${ }^{6,12}$. Low physical activity / sedentary behavior also has the potential to trigger complications of diabetes mellitus, repeated strokes and death ${ }^{13-16}$. Improving the stationary time (sedentary lifestyle) by 25-30 minutes per day can lower the risk of cardiovascular disease by $1 \%$ 
15,16. Therefore, stroke sufferers are advised to start physical activity exercise as soon as possible when the post stroke condition has stabilized. Thus, this review was conducted to identify various forms of physical activity for stroke patients. The results can be used to establish evidence-based, valid and reliable information concerning rehabilitation through physical exercise for stroke patients.

\section{Method}

This scoping review was compiled using Arksey and O'Malley's five-stage framework ${ }^{17}$. More details on our research protocol can be found below. In this section, we provide an overview of the steps.

\subsection{Identifying the research question}

Based on the purpose of this review, the formulation of this research question was: what physical activity can stroke patients do.

\subsection{Identifying studies}

Literature search was performed on the PubMed,
Proquest, and DOAJ databases using the keywords: "physical activity OR exercise AND stroke". The articles selected are: (a) articles published in the last 5 years (2015-2020), (b) in English, and (c) in full text. The articles that were excluded were articles that were not in accordance with the objectives of the scoping review and articles in the form of a review.

\subsection{Selecting studies}

Researchers independently screened the published papers, first using the title and abstract approaches. Titles and abstracts were checked and then articles within the last 5 years of publication were scanned. Articles were also screened by excluding duplicate articles. To avoid duplication, all articles detected during the search were entered in the Mendeley application to detect duplicated articles. The screening results then were screened according to the inclusion and exclusion criteria

\subsection{Charting the data}

Data extraction for each included article was in the form of a matrix (table). The articles that have

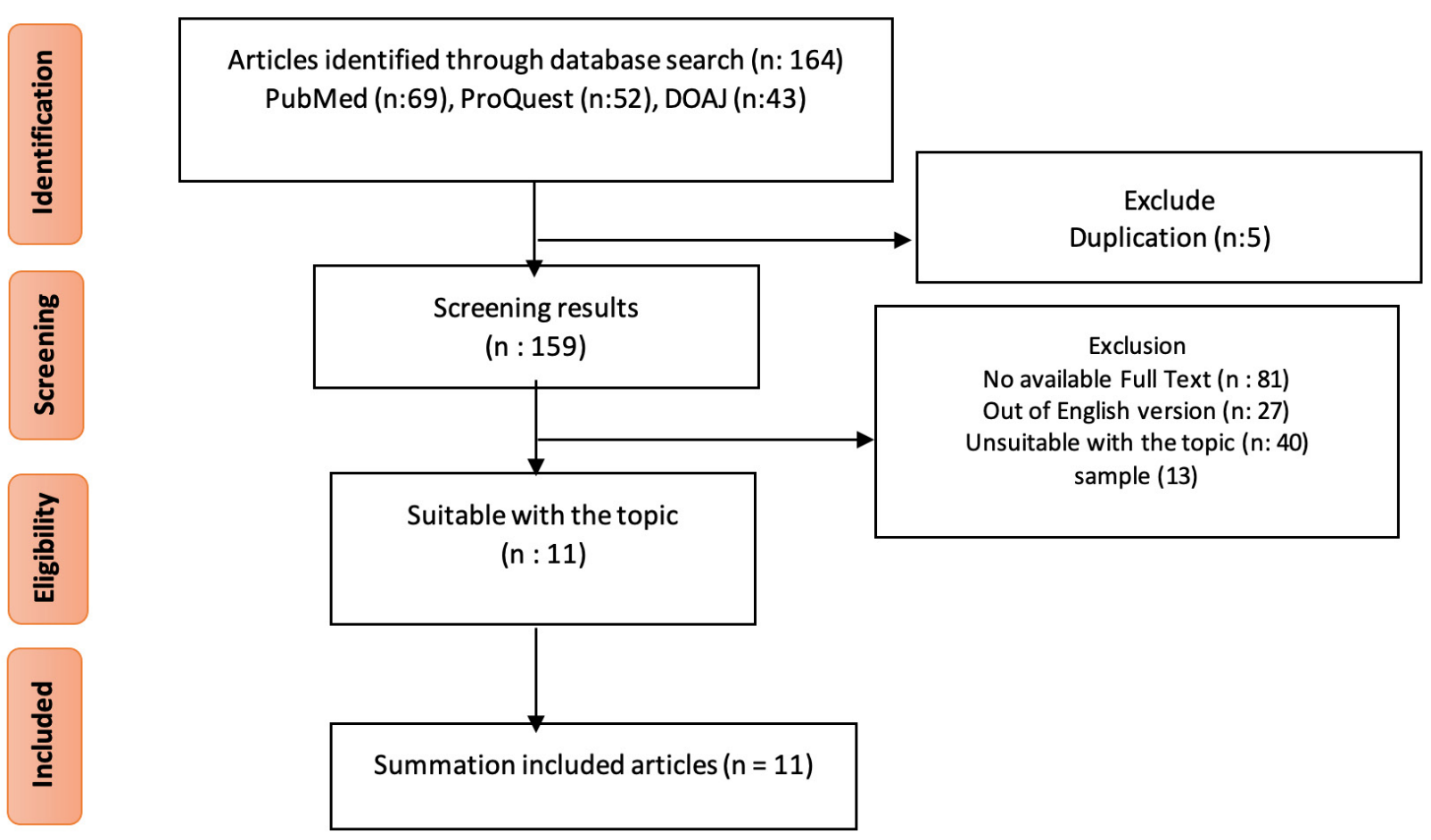

Figure 1. Study selection flowchart 
been included were then extracted based on the details of publication and research, the author, year of publication, exercise/physical activity, setting, and results. The data obtained were analyzed and arranged systematically.

\subsection{Collating, summarizing, and reporting results}

Descriptive qualitative content analysis methods were used to synthesis and analysis the data

\section{Result}

\subsection{Search Result}

Based on predetermined keywords, there were 164 identified articles. After the inclusion criteria were applied, the duplication of articles screened and their suitability for the purpose of writing this literature review, 11 articles were selected to be included in this literature review.

\subsection{Physical activity of stroke patients}

Based on the results of the analysis (Table 1), the authors identified physical activity / physical exercise that can be performed by stroke patients including progressive resistance and balance (PRB) training ${ }^{18,19}$, locomotors training: (walking on a treadmill with body weight support and walking on the ground) ${ }^{18}$, selective movements of the upper and lower trunk of the body in a supine position and sitting using a stable support / base or unstable support (Swiss ball $)^{20}$, core stability training ${ }^{21,22}$, aerobic (AT) and resistance training $(\mathrm{RT})^{23,24}$, aerobic training ${ }^{25}$, walking exercises $^{26}$, and task-oriented training ${ }^{27,28}$.

\section{Discussion}

Physical activity that can be performed by stroke patients consists of several types, including balance exercises (i.e., core stability training, progressive resistance and balance (PRB) training, selective movements of the upper and lower trunk of the body in a supine position and sitting using a stable support / base or unstable support (Swiss ball)), walking exercises (i.e., locomotors training: (walking on a treadmill with body weight support and walking on the ground) and walking exercises), physical fitness training (i.e., aerobic training, aerobic (AT) and resistance training (RT), and exercise modification in the form of daily activities, namely task-oriented training.

Physical activity is an important part of the rehabilitation phase for stroke patients. Full family or caregiver assistance predisposes the patient to immobility. As a result, the body, especially the limbs, becomes weaker, gets tired easily and feels heavy movement. This sedentary pattern in turn increases the risk of recurrent stroke and secondary complications ${ }^{25}$.

Physical activity is the main health behavior for stroke sufferers as a form of health management and maintenance. Physical activity with certain modifications can reduce the risk of cardiovascular disease and protect the incidence of stroke recurrence. Modifications can be made in the form of basic activities such as daily activities at home ${ }^{29,30}$. Physical activity programs are structured based on the basic principles of motor learning such as intensive, specific tasks, included challenges and exercises $^{31}$.

The duration, intensity, and frequency of exercise are also the main things to consider in order obtaining the best exercise outcome. Based on this literature review, it can be stated that almost all physical activity is done with duration of 30 minutes - 1 hour for approximately 2-3 times a week. The core stability training is carried out with a relatively shorter duration of 15-20 minutes but the frequency is increased up to 5 times a week. This schedule is in accordance with the basic principles of an exercise program including specificity, repetition, meaningful movements, and intensity ${ }^{32}$. In fact, physiological exercise will activate the stimulus signal to increase protein synthesis of actin fibers and muscle myosin. Therefore, with intense exercise, the amount of actin protein and muscle myosin will increase progressively and will increase muscle energy and strength, ultimately developing better coordination, so that the patient can support the body and perform movements ${ }^{33,34}$.

Thus, the results of this review can be used as a supporting guideline for determining exercises/ physical activities that can be recommended to stroke rehabilitation patients so that the patient's 
Table 1. (Continued)

\begin{tabular}{|c|c|c|c|c|}
\hline Physical activity & $\begin{array}{l}\text { Author, } \\
\text { year, design }\end{array}$ & Purpose & Setting & Outcomes \\
\hline $\begin{array}{l}\text { Aerobic (AT) and resistance } \\
\text { training (RT) }\end{array}$ & $\begin{array}{l}\text { Lund et al., } \\
2018, \text { RCT }\end{array}$ & $\begin{array}{l}\text { To investigate the } \\
\text { effect of different } \\
\text { types of physical } \\
\text { exercise on balance } \\
\text { performance } \\
\text { and whether } \\
\text { improved balance } \\
\text { correlates with } \\
\text { improved walking } \\
\text { performance }\end{array}$ & $\begin{array}{l}\text { Resistance and aerobic } \\
\text { exercise is carried out } 3 \text { days / } \\
\text { week for } 3 \text { months. }\end{array}$ & $\begin{array}{l}\text { the AT group increased peak } \\
\text { oxygen absorption by } 15.5 \\
(6.0-25.0) \% \text {, the RT group } \\
\text { increased the non-paretic } \\
\text { knee extensor strength by } \\
35.1(18.3-51.9) \% \text { All groups } \\
\text { improved balance (6, } 0 \text { ( } 95 \% \\
\text { Cl: } 3.2-8.8) \%), \text { maximum } \\
\text { walking speed (10.2 } \\
\text { (6.5-14.0)\%), and } 6 \text { minutes } \\
\text { walking }(12.4(8.8-15.9) \%) \\
\text { Physical exercise improves } \\
\text { balance and walking } \\
\text { performance }\end{array}$ \\
\hline Aerobic training & $\begin{array}{l}\text { Mansfield } \\
\text { et al., 2016, } \\
\text { cohort }\end{array}$ & $\begin{array}{l}\text { to evaluate the } \\
\text { effect of exercise } \\
\text { programs and } \\
\text { self-management } \\
\text { on participation } \\
\text { in independent } \\
\text { physical activity }\end{array}$ & $\begin{array}{l}\text {-Combined aerobic exercise } \\
\text { with a self-management } \\
\text { program } \\
- \text { Training sessions: warm up } \\
3-5 \text { minutes, cool down with } \\
\text { low intensity training, and } 20- \\
30 \text { minutes of aerobic exercise } \\
\text {-Frequency: } 3 \text { times a week for } \\
6 \text { weeks }\end{array}$ & $\begin{array}{l}\text { expected higher outcomes } \\
\text { for sport, less resistance to } \\
\text { physical activity, and higher } \\
\text { participation in physical } \\
\text { activity }\end{array}$ \\
\hline Walking exercise & $\begin{array}{l}\text { Andreasen } \\
\text { et al., 2020, } \\
\text { quasi RCT }\end{array}$ & $\begin{array}{l}\text { to examine } \\
\text { patterns of post- } \\
\text { stroke physical } \\
\text { activity and the } \\
\text { relationship of } \\
\text { these patterns to } \\
\text { parameters }\end{array}$ & $\begin{array}{l}30 \text { minutes duration and } \\
\text { frequency } 6-7 \text { times per week } \\
\text { for } 3 \text { months }\end{array}$ & $\begin{array}{l}\text { Step count and regularity } \\
\text { were linearly correlated ( } p \\
<0.001) \text {. The measures and } \\
\text { their associated complexity } \\
\text { were squared ( } r 2=0.70 \text { for } \\
\text { mean, } 0.64 \text { for daily values). } \\
\text { The complexity is affected by } \\
\text { the seasons between spring } \\
\text { and winter ( } p=0.019 \text { ). } \\
\text { Season has no effect on steps } \\
\text { or structure. Rainfall has no } \\
\text { effect on steps or complexity. }\end{array}$ \\
\hline $\begin{array}{l}\text { Task-Oriented training } \\
\text { (Reaching, grasping, } \\
\text { manipulating an object): } \\
\text { - Brushing teeth } \\
\text { - Hand writing } \\
\text { - Holds the spoon } \\
\text { - Drink } \\
\text { Open a book page }\end{array}$ & $\begin{array}{l}\text { Israely et } \\
\text { al., 2017, } \\
\text { case report }\end{array}$ & $\begin{array}{l}\text { Seeing the effect } \\
\text { of task-oriented } \\
\text { training on hand } \\
\text { and arm function }\end{array}$ & $\begin{array}{l}\text { One exercise session of two } \\
\text { minutes (the task is repeated } \\
8-15 \text { times). Each set of } \\
\text { exercises can be repeated } 4-5 \\
\text { times. }\end{array}$ & $\begin{array}{l}\text { Significant improvement in } \\
\text { hand function in proximal } \\
\text { and distal skills. emphasized } \\
\text { the importance of intensive } \\
\text { task-oriented training during } \\
\text { the first } 3 \text { months after stroke } \\
\text { to support natural healing of } \\
\text { the lesion area. }\end{array}$ \\
\hline $\begin{array}{l}\text { Task-oriented training: } \\
\text { - drink water from a glass } \\
\text { - lifting a glass of water to } \\
90^{\circ} \text { shoulder flexion } \\
\text { - move } 5 \text { crystals from table } \\
\text { to box } \\
\text { - wiping the table with a } \\
\text { towel with elbows extended } \\
\text { - grasps and releases a } 6 \mathrm{~cm} \\
\text { diameter tennis ball } \\
\text { comb the hair }\end{array}$ & $\begin{array}{l}\text { Thant.A.A } \\
\text { et al., 2019, } \\
\text { RCT }\end{array}$ & $\begin{array}{l}\text { To determine the } \\
\text { effect of task- } \\
\text { oriented training } \\
\text { on the functional } \\
\text { performance of the } \\
\text { upper extremities } \\
\text { paretics in patients } \\
\text { with subacute } \\
\text { stroke }\end{array}$ & $\begin{array}{l}\text {-Practicing } 3 \text { out of } 6 \\
\text { functional tasks selected } \\
\text { according to his wishes } \\
\text { - } 1 \text { session for } 1 \text { hour, warm up } \\
\text { for } 10 \text { minutes, practice the } \\
\text { task for } 50 \text { minutes. } \\
\text {-Every } 15 \text { minutes of walking } \\
\text { exercise given a } 2.5 \text { minute } \\
\text { rest period then resumed. } \\
\text {-Exercise is done } 5 \text { sessions / } \\
\text { week for } 4 \text { weeks } \\
\text {-Prior to training, the task is } \\
\text { demonstrated to participants } \\
\text { with reference to their } \\
\text { unaffected Upper Extremity }\end{array}$ & $\begin{array}{l}\text {-All participants complete } \\
\text { their training program. } \\
\text {-Much more significant } \\
\text { improvements to the Wolf } \\
\text { Motor Function Test, motor } \\
\text { portion of the Fugl-Meyer } \\
\text { assessment of upper } \\
\text { extremity, and the hand } \\
\text { function domain of the } \\
\text { Stroke Impact Scale. } \\
\text {-No serious side effects were } \\
\text { observed during or after } \\
\text { training }\end{array}$ \\
\hline
\end{tabular}


functional recovery, especially physical function, can be achieved according to the patient's rehabilitation target.

\section{Conclusion}

Through this review, empirical evidence identified findings regarding physical activity in stroke patients which provides the basis for routine implementation. Several physical activity exercises were identified to be the exercises that stroke patients can perform with each of them having goals and benefits in the physical functional recovery of stroke patients. Physical activity should be done regularly and take into account the duration, intensity, and frequency of the exercise in relation to a patient's ability and stamina. This review reveals how physical activity plays an important role in the physical improvement of stroke patients.

\section{Acknowledgement}

This study has no specific grants from any agencies in the public sector, commercial, or non-profit section.

\section{Conflict of interests}

There is no conflict of interest.

\section{References}

1. Bejot Y, Daubail B, Giroud M. Epidemiology of stroke and transient ischemic attacks: Current knowledge and perspectives. Rev Neurol (Paris). 2016;172(1):59-68.

2. Krishnamurthi R V., Ikeda T, Feigin VL. Global, regional and country-specific burden of ischaemic stroke, intracerebral haemorrhage and subarachnoid haemorrhage: a systematic analysis of the global burden of disease study 2017. Neuroepidemiology. 2020;54(2):171-9.

3. American Stroke Association. Guidelines for the early management of patients with acute ischemic stroke: 2019 update to the 2018 guidelines for the early management of acute ischemic stroke a guideline for healthcare professionals from the American Heart Association/American Stroke A. Vol. 50, Stroke. 2019. 344-418 p.

4. Jeon SH, Lee SM, Kim JH. Therapeutic effects of reaching with forward bending of trunk on postural stability, dynamic balance, and gait in individuals with chronic hemiparetic stroke. J Phys Ther Sci. 2015;27(8):2447-2451 5p.

5. Park GT, Kim M. Correlation between mobility assessed by the modified rivermead mobility index and physical function in stroke patients. J Phys Ther Sci. 2016;28(8):2389-92.

6. Billinger SA, Arena R, Bernhardt J, Eng JJ, Franklin $B A$, Johnson $C M$, et al. Physical activity and exercise recommendations for stroke survivors: a statement for healthcare professionals from the American Heart Association/American Stroke Association. Stroke. 2014;45(8):2532-53.

7. Van Duijnhoven HJR, Heeren A, Peters MAM, Veerbeek JM, Kwakkel G, Geurts $A C H$, et al. Effects of exercise therapy on balance capacity in chronic stroke: systematic review and metaanalysis. Stroke. 2016;47(10):2603-10.

8. Belfiore P, Miele A, Gallè F, Liguori G. Adapted physical activity and stroke: a systematic review. J Sports Med Phys Fitness. 2018;58(12):186775.

9. Nozoe M, Kubo H, Furuichi A, Kanai M, Yamamoto $M$, Kobayashi $M$, et al. Physical activity, physical function, and quadriceps muscle thickness in male patients with sub-acute stroke during hospitalization: a pilot study. Eur Neurol. 2019;80(3-4):157-62.

10. Gothe NP, Bourbeau K. Associations between physical activity intensities and physical function in stroke survivors. Am J Phys Med Rehabil. 2020;99(8):733-8.

11. Han P, Zhang $\mathrm{W}$, Kang $L$, Ma $Y, F u ~ L$, Jia L, et al. Clinical evidence of exercise benefits for stroke [Internet]. Vol. 1000, Exercise for Cardiovascular Disease Prevention and Treatment. Springer Nature Singapore; 2017. 187-210 p. Available from: http://link.springer.com/10.1007/978981-10-4304-8

12. Feigin $\mathrm{VL}$, Forouzanfar $\mathrm{MH}$, Krishnamurthi $\mathrm{R}$, Mensah GA, Connor M, Bennett DA, et al. Global and regional burden of stroke during 1990-2010: findings from the Global Burden of Disease Study 2010. Lancet. 2016;383(9913):245-55.

13. Saunders DH, Mead GE, Fitzsimons C, Kelly $P$, van Wijck $F$, Verschuren $O$, et al. Interventions 
for reducing sedentary behaviour in people with stroke. Cochrane Database Syst Rev. 2018;2018(4).

14. Ainsworth BE, Haskell WL, Herrmann SD, Meckes N, Bassett DR, Tudor-Locke C, et al. 2011 compendium of physical activities: a second update of codes and MET values. Med Sci Sports Exerc. 2011;43(8):1575-81.

15. Fitzgerald JD, Johnson L, Hire DG, Ambrosius WT, Anton SD, Dodson JA, et al. Association of objectively measured physical activity with cardiovascular risk in mobility-limited older adults. J Am Heart Assoc. 2015;4(2).

16. Young DR, Hivert MF, Alhassan S, Camhi SM, Ferguson JF, Katzmarzyk PT, et al. Sedentary behavior and cardiovascular morbidity and mortality: a science advisory from the American Heart Association. Circulation. 2016;134(13):e262-79.

17. Arksey H, O'Malley L. Scoping studies: Towards a methodological framework. Int J Soc Res Methodol Theory Pract. 2005;8(1):19-32.

18. Rose DK, Nadeau SE, Wu SS, Tilson JK, Dobkin $\mathrm{BH}, \mathrm{Pei} \mathrm{Q}$, et al. Locomotor training and strength and balance exercises for walking recovery after stroke: response to number of training sessions. Phys Ther. 2017;97(11):1066-74.

19. Vahlberg B, Cederholm T, Lindmark B, Zetterberg $L$, Hellström K. Short-term and long-term effects of a progressive resistance and balance exercise program in individuals with chronic stroke: a randomized controlled trial. Disabil Rehabil. 2017;39(16):1615-22.

20. Karthikbabu S, Chakrapani M, Ganesan S, Ellajosyula R, Solomon JM. Efficacy of trunk regimes on balance, mobility, physical function, and community reintegration in chronic stroke: A parallel-group randomized trial. J Stroke Cerebrovasc Dis. 2018;27(4):1003-11.

21. Cabanas-Valdés R, Bagur-Calafat C, GirabentFarrés $M$, Caballero-Gómez FM, Du Port De Pontcharra-Serra H, German-Romero A, et al. Long-term follow-up of a randomized controlled trial on additional core stability exercises training for improving dynamic sitting balance and trunk control in stroke patients. Clin Rehabil. 2017;31(11):1492-9.
22. Haruyama K, Kawakami M, Otsuka T. Effect of core stability training on trunk function, standing balance, and mobility in stroke patients: a randomized controlled trial. Neurorehabil Neural Repair. 2017;31(3):240-9.

23. Marzolini S, Brooks $D$, Oh $P$, Jagroop $D$, Maclntosh BJ, Anderson ND, et al. Aerobic with resistance training or aerobic training alone poststroke: A secondary analysis from a randomized clinical trial. Neurorehabil Neural Repair. 2018;32(3):209-22.

24. Lund C, Dalgas U, Grønborg TK, Andersen $H$, Severinsen $K$, Riemenschneider $M$, et al. Balance and walking performance are improved after resistance and aerobic training in persons with chronic stroke. Disabil Rehabil. 2018;40(20):2408-15.

25. Mansfield A, Knorr S, Poon V, Inness EL, Middleton L, Biasin L, et al. Promoting optimal physical exercise for life: an exercise and self-management program to encourage participation in physical activity after discharge from stroke rehabilitation: feasibility study. Stroke Res Treat. 2016;(5).

26. Andreasen SC, Wright TR, Crenshaw JR, Reisman DS, Knarr BA. Relationships of linear and nonlinear measurements of post-stroke walking activity and their relationship to weather. 2020;(2).

27. Israely S, Leisman G, Carmeli E. Improvement in arm and hand function after a stroke with taskoriented training. BMJ Case Rep. 2017;2017:17.

28. Thant AA, Wanpen $S$, Nualnetr N, Puntumetakul $\mathrm{R}$, Chatchawan U, Hla KM, et al. Effects of taskoriented training on upper extremity functional performance in patients with sub-acute stroke: A randomized controlled trial. J Phys Ther Sci. 2019;31(1):82-7.

29. Bailey RR. Promoting physical activity and nutrition in people with stroke. Am J Occup Ther. 2017;1-5.

30. Fanchamps MHJ, Horemans HLD, Ribbers GM, Stam HJ, Bussmann JBJ. The accuracy of the detection of body postures and movements using a physical activity monitor in people after a stroke. Sensors (Switzerland). 2018;18(7). 
31. Kantak SS, Sullivan KJ, Fisher BE, Knowlton BJ, Winstein CJ. Neural substrates of motor memory consolidation depend on practice structure. Nat Neurosci. 2010;13(8):923-5.

32. Kleim JA, Jones TA. Principles of experiencedependent neural plasticity: Implications for rehabilitation after brain damage. J Speech, Lang Hear Res. 2008;51(1):225-39.
33. Powers SK, Howley ET. Exercise physiology: Theory and application to fitness and performance. tenth. Vol. 18, The American Journal of Sports Medicine. New York: McGraw Hill Education; 2018. 316-320.

34. Sherwood L, Ward C. Human Physiology: From Cells to Systems. Fourth. Canada: Saunders Elsevier; 2019. 965 p. 